Indonesian Journal of Medicine (2017), 2(1): 36-41

https://doi.org/10.26911/theijmed.2017.02.01.04

\title{
Estradiol and Leptin in Women with Obesity, Overweight, and Normal Body Weight
}

\author{
Yulia Fitri',2), Gino Tann²), Rusdiana2) \\ ${ }^{1)}$ Health Polytechnic, Poltekkes of Aceh, Banda Aceh \\ 2)Biomedicine Science, Faculty of Medicine, North Sumatera University, Medan
}

\begin{abstract}
Background: Prevalence of obesity on women was higher than men. Obesity was related to the resistance of leptin hormone. Estradio hormone also played an important role in energy metabolism and body weight control. The study aimed to discover the relationship between estradiol concentration with leptin concentration on women with obesity, overweight and normal body weight in Banda Aceh City.

Subjects and Method: The study was an analytic observational study with case control design. There were a total of 75 women of 20-40 year- old who were selected as research subjects by using purposive sampling. The research subjects were divided into 3 groups, namely obesity, over weight, and normal body weight. The study was conducted in Banda Aceh City in July - October 2014. Dependent variable of the study was women's body weight. Independent variables were leptin concentration which was investigated by using ELISA technique and estradiol concentration which was investigated by using $A x S Y M$ Estradiol Assay. The data was analyzed by using Spearman correlation test.

Results: The result of the study obtained the median value of estradiol concentration on normal group was higher than on obesity and overweight group, that was $63 \mathrm{Pg} / \mathrm{mL}(18-420)$. The average concentration of leptin on normal group is higher than obesity and overweight group, that was 4.56 $\mathrm{ng} / \mathrm{mL}$ (up to \pm 3.48 ). However, it did not find any correlation between the concentration of estradiol and the concentration of leptin on women with obesity, overweight and normal weight $(\mathrm{R}=$ $0.03 ; \mathrm{p}=0.121 ;$ ).

Conclusion: The study showed that women with obesity experienced the decreasing concentration of estradiol and leptin, however it did not find significant correlation between estradiol and leptin.
\end{abstract}

Keywords: estradiol, leptin, women with obesity, overweight, normal body weight

Correspondence:

Yulia Fitri. Health Polytechnic, Poltekkes of Aceh, Banda Aceh.

\section{BACKGROUND}

The increasing of obesity prevalence is a major health problem globally (Park dan Kim, 2012). About 2.8 million adults die every year related to overweight and obesity. In general more than $10 \%$ of the adult population in the world suffers from obesity, and almost300 million of it were women (WHO, 2013). In Indonesia the number of obesity keeps on growing. Based on Riskesdas (2013), on grown up men an increasing occurred from $13.9 \%$ in 2007 became $19.7 \%$ in 2013. Whereas on grown up women an increase occurred very extremely up to $18.1 \%$.
From $14.8 \%$ in 2007 became $32.9 \%$ in 2013 (Riskesdas, 2013).

Obesity has multifactorial etiology that involves genetic, metabolism, culture, psychosocial factor and change of life style that generates the increase of food intake and the decrease of energy expenditure (Fontaine et al., 2003) it leads to the y accumulation of excess body fat (PHE, 2014).

Obesity is related to leptin resistance which is hormone of adipose cell that is the first known to have signal of satiety markers (Sherwood, 2012) especially synthesized and secreted by subcutaneous white adipose cell 
so that the level of leptin serum is proportional with the mass of adipocyte tissue (Schuattle, 2012).

Leptin has a central role within energy homeostasis (Oral et al., 2002). Animal and human with leptin signal disorder endures hyperphagia and extreme energy utilization disorder (Gao dan Horvad, 2008). High concentration of leptin (hyperleptinemia) is found in obesity patients, where the leptin concentration strongly correlates with BMI and body fat percentage (Shah and Braverman, 2012).

Study on women and men shows the higher concentration of leptin on women than on men(Kon Koh et al., 2008; Oldstad et al., 2011) in which the background mechanism is not yet fully understood (Schutle, 2012). A study has reported a strong evidence that shows the role of estrogen in lipid metabolism within adipose tissue. Increasing fat mass on male mice with homozygous inactivation both estrogen receptor as well as aromatase gen and estrogen replacement are able to restore the condition within the model (Misso et al., 2003). In molecular level, it has demonstrated that estrogen suppress fat accumulation and influence lipoprotein lipase (LPL, the key enzyme that control energy metabolism, catabolism of plasma triglyceride into free fatty acid and glycerol) (Mammy et al., 2011).

Such as leptin, estrogen hormone reduce food intake and adiposity of body as well as increase the energy expenditure on animal and human from both sexes through hypothalamus mechanism (Gao and Horvad, 2008). Study on animal tries to demonstrate that there is suppression of fat accumulation by estrogen receptor through the mechanism of decrease in lipoprotein lipase (LPL) enzyme activity (Homma et al., 2000). Estradiol administration to animal in ovariectomy suppresses the development of obesity by reducing food intake and increase energy expenditure (Gao and Horvath, 2007).

The main area of estrogen receptor (ER) including the same area where leptin receptor (LepRs) occurs which is the area known for coordinating the metabolism function and gonad such as arcuate nucleus (ARC), ventromedial nucleus hypothalamus (VHM) and preoptic area (POA) (Gao and Horvath, 2008). Study on animal attempted to show that Shp2/ ERa in hypothalamus is related to signal of leptin and estrogen, indicating Shp2 coordination on leptin and estrogen signaling pathway (Zhou Y dan Rui L, 2013). The study aimed to discover the correlation of leptin concentration and estradiol concentration on women with obesity, overweight, and normal body weight in Banda Aceh city.

\section{SUBJECTS AND METHOD \\ 1. Research Design}

Thestudy was an analytic observational with case control design. The study was conducted from July-October 2014 in city of Banda Aceh. Blood sample collection was conducted in RSUD Meuraxa Banda Aceh and the investigation of estradiol dan leptin sample was conducted in Spectrum International Clinical Laboratory, Medan. The population of the study was 20-40 year-old women who domiciled in Banda Aceg city. The subject of the study was women who met the inclusion criteria which were: $20-40$ year-old women, in her $6^{\text {th }}$ day of menstrual cycle and approved the informed consent, did not suffer from cardiovascular, kidney, malignancy, hepatitis, and diabetes, did not consume long term medication that influence body weight, also exclusion criteria were underwent hormone therapy and had conducted ovariectomy. 
Indonesian Journal of Medicine (2017), 2(1): 36-41

https://doi.org/10.26911/theijmed.2017.02.01.04

The size of sample was 25 people for each group, therefore there was a total of 75 people which were divided into 3 (three) group namely obesity group, overweight group and normal body weight group. The sampling technique used was purposive sampling technique in accordance with the criteria of the study.

\section{Anamnesis, measuring of BMI and Waist Circumference (WC)}

The study begun with initial screening to determine the category of subject of the study by means of anamnesis process and the measuring of Body Mass Index (BMI) and waist circumference to determine the category of obesity, overweight and normal weight.

The process of anamnesis included analyzing the data on age, medical history, and use of drugs. Afterward BMI measuring was conducted by comparing body weight (Kg) with the square of height $\left(\mathrm{m}^{2}\right)$. Based on the criteria from The Asia Pasific Perspective (2000) and waist circumference according to the criteria of IDF (2006) to be considered normal category whenever BMI 18.5-22.9 kg/m² and WC $<80 \mathrm{~cm}$, overweight when $\mathrm{BMI}>23-24.9 \mathrm{~kg} / \mathrm{m}^{2}$ and $\mathrm{WC}$ $\geq 80 \mathrm{~cm}$, obesity when $\mathrm{BMI} \geq 25 \mathrm{~kg} / \mathrm{m}^{2}$ and $\mathrm{WC}>80 \mathrm{~cm}$. Anamnesis, BMI and WC measurement was conducted by enumerator who has follow prior training and every subject of the study had given approval after obtained informed consent.

\section{Blood Sample Collection and Inves- tigation}

Sample collection was conducted in the morning(08.00-09.00 IWST) after the subjects of the study conducted fasting for 1012 hours. Sample collection was conducted by taking cubital vein blood. Estradiol concentration measurement was conducted by using the AxSYM Estradiol assay based on micro particle technology Enzyme Immu- noassay. Leptin concentration was measured by means of ELISA (Enzyme-linked immunosorbent assay) method by using $D R G$ leptin Elisa Kit.

\section{Data Analysis}

Normality test was conducted by using Kolmogorov-Smirnov. To know the correlation of the concentration of estradiol and leptin, a correlation analysis was conducted by using Pearson test. If data were not normaly distributed then non-parametric test was conducted that was Spearman correlation test. Data analysis used SPSS program version 16.00.

\section{Ethical Clearance}

The study had obtained a permit from the Ethic Committee of Faculty of Medicine, North Sumatra University

\section{RESULTS}

The result of the study obtained the data on the measurement of BMI, WC, estradiol and leptin concentration as it was presented in Table 1 . The subjects of the study were between 20-40 year-old with the average age was 24 year-old. The average BMI of the subjects was $24.38 \mathrm{Kg} / \mathrm{m}^{2}$ (18.52-33.47).

The average waist circumference of the study was $81 \mathrm{~cm}(62 \mathrm{~cm}-115 \mathrm{~cm})$. the average leptin concentration on the entire groups was $5.79 \mathrm{mg} / \mathrm{mL}\left(\mathrm{SD}_{ \pm} 3.48\right)$, whereas the concentration of estradiol was 77.8 $\mathrm{Pg} / \mathrm{mol}\left(\mathrm{SD}_{ \pm} 57.8\right)$.

Table 2 showed the existence of positive correlation between estradiol and leptin $(\mathrm{r}=$ o.03), however it was statistically insignificant $(\mathrm{p}=0.121)$. The pattern was also seen on the correlation test result on each group of study subjects excluded obesity group, in which there was negative correlation between estradiol and leptin concentration with very weak correlation strength $(\mathrm{r}=0.16)$ and statistically insignficant $(\mathrm{p}=$ $0.221)$. 
Fitri et al./ Estradiol and Leptin in Women

Table 1. Distribution of age, body mass index, waist circumference on women with obesity, overweight, and normal weight, the concentration of estradiol and leptin

\begin{tabular}{lccccccc}
\hline \multicolumn{1}{c}{ Variables } & n & Mean & Median & SD & Min & Max & Normality Test \\
\hline BMI (Kg/m $\mathbf{m}^{2}$ ) & 75 & 24.65 & 24.38 & 3.85 & 18.52 & 33.47 & 0.003 \\
- Obesity & 25 & 29.17 & 28.56 & 2.23 & 25.47 & 33.47 & \\
- Overweight & 25 & 24.19 & 24.38 & 0.61 & 23.33 & 24.99 & \\
- Normal & 25 & 20.58 & 20.36 & 1.26 & 18.52 & 22.68 & \\
\hline Waist Circumference & & & & & & & \\
(cm) & 75 & 81.47 & 81 & 10.70 & 62 & 115 & 0.027 \\
- Obesity & 25 & 92.90 & 90 & 8.84 & 82 & 115 & \\
- Overweight & 25 & 81.76 & 81 & 3.01 & 77 & 88 & \\
- Normal & 25 & 70.44 & 70 & 4.36 & 62 & 78 & \\
\hline Leptin (ng/mL) & 75 & 5.79 & 4.56 & 3.48 & 1.24 & 16.76 & 0.200 \\
- Obesity & 25 & 8.30 & 7.44 & 3.62 & 2.20 & 16.76 & \\
- Overweight & 25 & 4.86 & 4.03 & 2.78 & 1.83 & 11.53 & \\
- Normal & 25 & 4.07 & 3.32 & 2.46 & 1.24 & 11.39 & \\
\hline Estradiol (Pg/mol) & 75 & 77.8 & 63 & 57.86 & 18 & 420 & 0.001 \\
- Obesity & 25 & 67.08 & 61 & 20.19 & 38 & 126 & \\
- Overweight & 25 & 65.16 & 59 & 31.46 & 18 & 184 & \\
- Normal & 25 & 101.28 & 70 & 89.8 & 41 & 420 & \\
& & & & 0 & & & \\
\hline
\end{tabular}

Table 2. Analysis of the correlation between estradiol and leptin concentration

\begin{tabular}{lccc}
\hline & Variables & \multicolumn{2}{c}{ Leptin } \\
\cline { 2 - 3 } & & $\mathbf{r}$ & $\mathbf{p}$ \\
\hline Estradiol & 0.03 & 0.121 \\
- Obesity & -0.16 & 0.221 \\
- Overweight & 0.14 & 0.260 \\
- Normal & 0.22 & 0.150 \\
\hline
\end{tabular}

\section{DISCUSSION}

The result of the study showed that median value of body mass index (BMI) on obesity group was $28.56 \mathrm{Kg} / \mathrm{m}^{2}(25.47-33.47)$ it is categorized as degree 1 of obesity. The average of samples' waist circumference was 81 cm (62-115). Both measurements show the value above the normal value of ideal weight measurement (IDF, 2006). It indicates the tendency of increasing risk of morbidity that is related to obesity which has come up on women aged $\leq 40$ years (Flegal et al., 2010).

The average value of estradiol and leptin concentration of study samples tended to be low, it shows there is a trend of the occurrence of deficiency for both hormones on women even before they hit menopause that may contribute to generate obesity. The low concentration of estradiol leads to the increasing activities of lipoprotein lipase (LPL), so fatty acid is not oxidized, and leads to the growing accumulation of fat and it is identified from the increasing size of waist circumference (Lofgren et al., 2004) as one of the indicators of abdominal obesity.

Theresult of the study is different from the study on premenopause African American (AA) women aged 25-45 year-old who endure abdominal obesity. The group has higher concentration of estradiol compared tonon Hispanic Caucasian (CA) women. The difference is probably because of different 
life style (Paxton et al., 2013) Combination of high fat consumption, low fiber and energy dense diet may generate increasing leptin and estrogen in hypothalamus (Zhao, 2013), estradiol level of consentration (Barnett et al., 2013). AA women probably has higher ovarian aromatase activity than CA women which is produced from polymorphisms CYP 19 and other biology factors such as leptin and Mullerian hormone (Marsh et al., 2011).

The result of correlation test of the whole samples showed that there was a significant correlation between estradiol and leptin, similarly, on each group. It is in accordance with the previous study in which estradiol reduce food intake not only by means of the interaction with leptin hormone, but also interact with other hormones in regulating food intake, such as insulin, ghrelin and NPY (Brown and Clegg, 2010) estrogen also directly works on central nervous system (CNS Meyer, 2011).

Based on correlation direction, it is seen that there is positive correlation between estradiol with leptin and the pattern is also seen on the result of correlation test of each sample group excluding obesity group. It means that increasing leptin concentration, is in line with the increasing of estradiol concentration, excluding obesity group, that shows the higher leptin concentration the lower estradiol concentration will be..

The previous study on animal attempted to show that E2 has the capability to lower down daily energy intake. However, the effect only occurs to individual who is resistant to leptin (Weight, 2012). The study on animal attempted to show the existence of coordination on the regulation signaling pathway leptin and estrogen by means of $\mathrm{SH} 2$ tirosin fosfatase which are related to receptor.

There is no correlation found between estradiol concentration and leptin concen- tration on women with obesity, overweight and normal weight. It needs to conduct early screening on risk factors of cardiovascular disorder for women with obesity and overweight. However, before hitting menopause seeing the trend of high leptin concentration indicates there is leptin resistance and the low estradiol concentration on women with obesity, even before hitting menopause may contribute to generate obesity as the risk factor of cardiovascular disease.

\section{REFERENCE}

Barnett JB, Woods MN, Rosner B (2001). Sex hormone levels in premenopausal African-American women with upper and lower body fat phenotypes. Nutr Cancer 41: 47-56.

Brown LM, Clegg DJ (2010). Central effects of estradiol in the regulation of food intake, body weight, and adiposity. $\mathrm{J}$ Steroid Biochem Mol Biol 122: 65-73.

Carr MC (2003). The emergence of the metabolic syndrome with menopause. $J$ Clin Endocrinol Metab 88(6): 24042411.

Flegal KM, Carroll MD, Ogden CL, Curtin LR (2010). Prevalence and trends in obesity among US adults 1999-2008. JAMA 303(3): 235-241.

Fontaine KR, Redden DT, Wang (2003). Years of Life Lost Due to Obesity. JAMA 289(2): 187-93.

Gao Q, Horvath T (2008). Cross-talk between estrogen and leptin signaling in the hypothalamus. Am J Physiol Endocrinol Metab 294: E817-E82.

Gao Q, Horvath T (2008). Cross-talk between estrogen and leptin signaling in the hypothalamus. Am J Physiol Endocrinol Metab 294: E817-E82.

International diabetes Federation. Diabetes. (2006). Atlas. $3^{\text {rd }}$ edn. Brussels; International Diabetes Federation.

Kon Koh K, Park SM, Quon MJ (2008). Leptin and cardiovascular disease: responsetotherapeutic interventions. Circulation 117(25): 3238-3249. 
Lofgren I, Herron K, Zern T, West K, Patalay Madhu, Shacher NS, Koo SI, Fernandez ML (2004). Waist Circumference is a better predictor than body Mass index of CHD risk in overweight premenopausal women. American Society for nutritional Sciences 00223166.

Mammy C, Calanchini M, Antelmi A, Cinti F, Giuseppe MC, Rosano, Lenzi L, Caprio M, Andrea Fabbri (2012). Androgens and Adipose Tissue in Males: A Complex and Reciprocal Interplay Hindawi Publishing Corporation International Journal of Endocrinology.

Marsh EE, Shaw ND, Klingman KM (2011). Estrogen levels are higher across the menstrual cycle in African-American women compared with Caucasian women. J Clin Endocrinol Metab 96: 3199-3206.

Meyer MR, Deborah J. Clegg, Eric R. Prossnitz, Matthias B (2011). Obesity, Insulin Resistance and Diabetes: Sex Differences and Role of Estrogen Receptors Acta Physiol (Oxf). 203(1): 259-269. doi:10.1111/j.1748-1716.201 0.02237.x.

Misso ML, Murata Y, Boon WC, Jones MEE, Britt KL, Simpson ER (2003). Cellular and molecular characterization of the adipose phenotype of the aromatasedeficient mouse, Endocrinology 144 (4): 1474-1480.

Olstad R, Florholmen J, Svartberg J, Jan H. Rosenvinge, Grethe SB (2011). Leptin in the General Population, Differences in Sex Hormones, Blood Lipids, Gender and Life Style Characteristics. The Open Behavioral Science Journal 5: 815.

Oral EA, Simha V, Ruiz E (2002). Leptin-replacement therapy for lipodystrophy. N Engl J Med 346(8): 570-578.

Park YS, Kim JS (2012). Obesity Phenotype and Coronary Heart Disease Risk as
Estimated by the Framingham Risk Score. Korean Med Sci 27: 243-249.

Paxton R, Denae WK, Celia GP, Connors SK, Hernandez M, Beverly J Gor, Lovell A (2013). Jones Associations Between Body Size and Serum Estradiol and Sex Hormone-Binding Globulin Levels in Premenopausal African American Women J Clin Endocrinol Metab 98 (3): E485-E490.

Public Health England (2014). Morbid Obesity. Available from http://www.noo. org.uk/NOO_about_obesity/morbid_ obesity (diakses 21 mei 2014).

Riskesdas (2013). Riset Kesehatan Dasar. Depkes RI. www.Litbang.depkes.go.id

Schuttle AE (2012) Leptin: a Cardiovascular Perspective. Hypertension in Africa Research Team (HART). JEMDSA 17 (2).

Shah A. Hernandez A, Mathur D, Budoff MJ, Kanaya AMD (2012). Adipokines and body fat composition in south asians: results of the metabolic syndrome and atherosclerosis in south Asians Living in america, study Int $\mathrm{J}$ Obes (Lond) 36(6): 810-816.

Sherwood L (2012). Fisiologi manusia dari sel ke system. Edisi 6. Jakarta: Penerbit buku kedokteran EGC.

Weight C, Hertrampt T, Kluxen FM, Flenker U, Hulsemann F, KH Fritzemeier, Diel $P$ (2013). Molecular effects of ER alpha and beta-selective agonists on regulation of energy homeostasis in obese female Wistar rats. Molecular and Cellular Endocrinology 377: 147-158.

WHO (2013). Obesity and overweight. Available from http://www.who.int/mediacentre/factsheets/fs311/en/

Zhou Y, Rui L (2013). Leptin Signaling and Leptin Resistance. Front Med 7(2): 207-222. 